\title{
Logistic regression analysis of some environmental factors affecting days open in Iranian primiparous Holstein cows
}

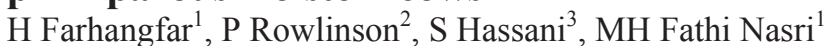 \\ ${ }^{1}$ Birjand University, Birjand, Islamic Republic of Iran \\ ${ }^{2}$ University of Newcastle, Newcastle-Upon-Tyne, United Kingdom, \\ ${ }^{3}$ Gorgan University of Agricultural Sciences and Natural Resources, Gorgan, Islamic Republic of Iran \\ Email: hfarhangfar2003@yahoo.co.uk
}

Introduction In practical dairy cattle breeding schemes, both production and reproduction performance of animals are of particular economic importance. Over the past decades, most selection pressure has been on cow's milk yield resulting in increasing fertility problems. Profitability of a dairy farm enterprise is a function of several factors among which good reproduction performance of animals is of great importance. A cow with higher conception rate is expected to produce more income over her herd life for a breeder. Among different measures associated with cow fertility, days open has long been considered by researchers. Genetic and non-genetic factors influence days open. In much research, days open has been analysed by a linear model in which a normal distribution is assumed for the trait. However, few studies have been undertaken to evaluate factors affecting open days using a non-linear model. The main aim of this study was to analyse some environmental factors associated with days open in Iranian first lactation Holstein cows using a logistic regression approach.

Material and methods Records were collected from 5511 Iranian first lactation Holstein heifers distributed in 64 herds from Mashhad, Iran between 1994 and 2007. Average lactation milk yield, Holstein gene percentage, air temperature at calving day, age at first calving and days open were $7413 \mathrm{~kg}, 93.42 \%, 16.05{ }^{\circ} \mathrm{C}, 26.33$ months and 114 days, respectively. Days open was not normally distributed. A logistic regression model (Fang, 2005) was fitted to the data (SAS Institute Inc. 2004). In the data file, as applied by Cole and Null (2009), days open lower than 50 days and greater than 250 days were set to 50 and 250 days, respectively. In the model, fixed environmental effects of herd, year and season of calving along with two-level effects of milk yield (MCODE), age at first calving (ACODE), Holstein gene percentage (HCODE) and air temperature at calving day (TCODE) were included. Two-level effect for each environmental factor was set based on its average. Days open was also defined as a dichotomous dependent variable based upon its average. For logistic regression model, the probability of days open greater than its average was modeled.

Results Herd, year and season of calving as well as milk production level were found to be highly (P $<0.001)$ associated with the probability of days open being greater than average. Days open was not significantly affected by ACODE, HCODE and TCODE. In Table 1, odds ratio estimates obtained for season of calving and milk production level are presented.

Table 1 Odds ratio estimates (95\% confidence interval) for different levels of calving season and milk production

\begin{tabular}{llll}
\hline \hline Effect & Summer & Autumn & Winter \\
\hline Season of calving (as compared to spring calvers) & $0.591(0.501-0.697)$ & $0.714(0.579-0.880)$ & $0.913(0.736-1.133)$ \\
Milk production level (as compared to lower than its & $2.457(2.139-2.823)$ & & \\
average) & & & \\
\hline \hline
\end{tabular}

Conclusions Many studies (Kirkpatrick, 1999) have shown that days open is of low heritability indicating that most phenotypic variation is explained by environmental factors. Improving reproduction performance, therefore, could be achieved by herd management practices such as providing better nutrition and health. Furthermore, as pointed out by Kirkpatrick (1999), crossbreeding could be an effective tool for exploiting heterosis in a low heritability trait. The results obtained in this study revealed that as compared to spring calvers, cows calving in summer had a lower chance of days open greater than the average (114 days) and that winter calving cows are expected to experience more fertility difficulties as compared to summer and autumn calvers. As expected, high milk producing cows were found to have greater chance for longer open days suggesting that there is a need to take into account of open days as the genetic evaluation of dairy cows is undertaken.

Acknowledgements The authors would like to express especial thanks to the Agricultural Jihad Organisation, Mashhad, Iran for providing the data used in this research.

\section{References}

Cole, J.B. and Null, D.J. 2009. Journal of Dairy Science, 92, 2248-2258.

Fang, J.Q. 2005. Medical Statistics and Computer Experiments. World Scientific Publishing.

Kirkpatrick, B.W. 1999. In: The Genetics of Cattle. Eds. R. Fries and A. Ruvinsky. CAB International. Pages 391-410.

SAS Institute Inc. 2004. SAS/STAT 9.1 User's Guide, NC: SAS Institute Inc. 